\title{
Pendekatan Tematik Dalam Pembelajaran Bahasa Arab
}

\author{
Maimunsyah \\ Dosen Prodi Pendidikan Bahasa Arab STKIP Al Washliyah Banda Aceh \\ Email.maimunsyah85@gmail.com
}

\begin{abstract}
Abstrak
Pendekatan dalam pembelajaran merupakan cara atau pola yang digunakan oleh pengajar dalam suatu pembelajaran agar semua kegiatannya berlangsung dengan baik dan memungkinkan para siswa belajar sesuai dengan tujuan tertentu. Salah satu pola perubahan kurikulum 2013 yaitu dari pengelolaan pembelajaran secara terpisah (mata pelajaran) menjadi pembelajaran tematik. Dalam pendekatan pembelajaran termatik, pembelajaran bahasa Arab disusun dari berbagai macam keterampilan berbahasa, yaitu mendengar (istima'), membaca (qiraah),berbicara (kalam)dan menulis (kitabah) dalam satu topik di materi pembelajaran. Penelitian ini bertujuan untuk mengetahui landasan, karakteristik dan manfaat pendekatan tematik dalam pembelajaran tematik. metode yang digunakan ialah penelitian pustaka (library research) yang mengambil sumber dari data dari teori-teori secra kepustakaan. Hasilnya menunjukkan bahwa landasan pendekatan tematik dalam pembelajaran bahasa Arab berupa: Landasan filosofis, landasan psikologis dan landasan hukum. Karakteristik pendekatan tematik dalam pembelajaran bahasa Arab yaitu: Pembelajaran berpusat pada peserta didik, memberi pengalaman langsung kepada peserta didik, Penyatuan keterampilan bahasa dalam satu materi, Hasil pembelajaran dapat berkembang sesuia dengan minat dan kebutuhan dan Pembelajaran bahasa Arab dapat berlangsung fleksibel dan lebih efesien. Manfaat pendekatan tematik dalam pembelajaran bahasa Arab yaitu: meningkatkan pemahaman konseptual, Peserta didik mudah memusatkan perhatian karena beberapa keterampilan, Peserta didik dapat mempelajari pengetahuan dan mengembangkan berbagai keterampilan bahasa Arab, melatih peserta didik untuk banyak membuat hubungan beberapa keterampilan bahasa dan Menghemat waktu karena beberapa keterampilan dikemas dalam tema.
\end{abstract}

\section{Kata kunci: Tematik, Pembelajaran, Bahasa Arab}

\section{Pendahuluan}

Pendidikan pada hakikatnya bertujuan mengembangkan kemampuan dan membentuk karakter serta peradaban bangsa yang bermartabat dalam rangka mencerdaskan kehidupan bangsa, berfungsi untuk mengembangkan potensi peserta didik agar menjadi manusia yang beriman, bertakwa kepada Tuhan Yang Maha Esa, berakhlak mulia dan berilmu. Hal tersebut tercantum dalam Undang-Undang Nomor 20 Tahun 2003 tentang Sistem Pendidikan Nasional.

Pendidikan ialah usaha sadar, terencana dan terstruktur demi mewujudkan kegiatan belajar, keterampilan. Pendidikan juga merupakan upaya dalam rangka menyiapakan murid melalui bimbingan, pengajaran dan latihan. Suatu proses belajar yang direncanakan baik di kelas maupun di luar kelas, diharapkan dapat dikondisikan 
sesuai dengan suasana peserta didik. Terlebih bagi peserta didik tingkat sekolah dasar. Kegiatan belajar mengajar merupakan proses yang di dalamnya terdapat beberapa unsur utama. Guru, siswa, materi dan metode ialah komponen penting yang terdapat dalam suatu proses belajar mengajar.

Dalam suatu proses pembelajaran terdapat komponen siswa sebagai objek yang sedang belajar dan guru bertindak sebagai pengajar guna memberikan materi pelajaran untuk terjadi perubahan dalam diri siswa. Usaha menyampaikan materi atau keterampilan kepada siswa harus melalui suatu pendekatan pembelajaran yang tepat. Pendekatan yang digunakan dalam belajar hendaknya mengacu tujuan atau standar kompetensi yang telah dirumuskan dan ditetapkan dalam setiap pelajaran. Oleh sebab itu, pendekatan pembelajaran merupakan salah satu bagian integral yang dapat mempengaruhi capaian hasil belajar. Sukses dan gagalnya pencapaian terhadap tujuan tersebut, dapat dipengaruhi oleh pendekatan pembelajaran yang diterapkan oleh guru.

Webb dan Pearson dalam Anwar Novianto, (2015:3) mengungkapkan bahwa proses awal dalam pembelajaran tematik ialah menganalisis tema yang akan dipilih. Suatu model tematik sebagai kesatun tema-tema yang memuat gagasan pengajaran dan menginterasikan beberapa topik. Pengajar sebagai pendidik harus menyediakan kegiatan yang relevan dan konteks yang sangat bermakna bagi peserta didik. Implementasi pembelajaran tematik, menuntut kemampuan yang optimal bagi pengajar karena kurikulum berbasis kompetensi atau standar isi juga memberi peluang bagi kepala sekolah, pengajar dan peserta didik untuk melakukan inovasi di sekolah berkaitan dengan kurikulum, pembelajaran dan manajerial, (Darwis Sasmedi, 2008).

\section{Pendekatan Tematik Dalam Pembelajaran}

Pendekatan dalam pembelajaran merupakan cara atau pola yang digunakan oleh pengajar dalam suatu pembelajaran agar semua kegiatannya berlangsung dengan baik dan memungkinkan para siswa belajar sesuai dengan tujuan tertentu. Dalam dunia pendidikan, terdapat banyak pendekatan pembelajaran yang bisa digunakan dalam pembelajaran. Penggunaan suatu pendekatan harus disesuaikan dengan karakteristik materi yang akan diajarkan. Suatu pendekatan dalam pembelajaran harus terencana dengan baik dan disesuaikan dengan kebutuhan materi yang akan di diajarkan ke para siswa.

Penerapan kurikulum 2013 di Indonesia menjadi salah satu upaya pemerintah dalam mewujudkan tercapainya tujuan pendidikan nasional. Salah satu pola perubahan kurikulum 2013 yaitu dari pengelolaan pembelajaran secara terpisah (mata pelajaran) menjadi pembelajaran tematik. Karakteristik pembelajaran kurikulum 2013 menggunakan model pembelajaran tematik integratif, pendekatan saintifik, kontekstual dan pembelajaran berbasis proyek. Proses pembelajaran mulai dari kelas I hingga kelas VI menggunakan model pembelajaran tematik integratif. suatu sistem pembelajaran yang memungkinkan peserta didik, baik secara individu maupun kelompok lebih aktif menggali dan menemukan konsep serta prinsip-prinsip keilmuan secara holistik, bermakna dan otentik. Kurikulum ini menerapkan pembelajaran dengan tema-tema yang jauh lebih aktual dan kontekstual dalam kehidupan sehari-hari. Maknanya, pelaksanaan kurikulum tematik pada dasarnya adalah penerapan konsep pembelajaran yang menggunakan tema dalam kontekstualisasi beberapa mata pelajaran. Cara ini akan 
membuat para siswa mendapatkan pengalaman nyata yang sangat berarti (Ariyanti, 2017:2).

Menurut Fogarty dalam Tien Kartini (2012), model pembelajaran dengan pendekatan tematik merupakan model pembelajaran yang pengembangannya dimulai dengan menentukan topik tertentu sebagai tema atau topik sentral, kemudian tema ditetapkan maka selanjutnya tema tersebut dijadikan dasar untuk menentukan dasar subu-sub tema dari bidang studi lain yang terkait. Pembelajaran tematik merupakan pendekatan pembelajaran yang menyatukan berbagai kecakapan dan berbagai mata pelajaran ke dalam berbagai tema. Penyatuan tersebut dilakukan dalam dua hal, yaitu penyatuan sikap, keterampilan dan pengetahuan dalam proses pembelajaran dan penyatuan berbagai konsep dasar yang berkaitan. Tema memiliki makna dari berbagai konsep dasar sehingga konsep dasar yang dipelajari siswa tidak hanya sebagian (Nahak et al., 2019:875). Suatu pembelajaran dengan menggunakan pendekatan tematik merupakan suatu pendekatan dalam pembelajaran yang menggabungkan berbagai kompetensi dari beberapa mata pelajaran ke dalam suatu tema.

Muklis (2012:63) menyebutkan bahwa pada dasarnya setiap anak memiliki kemampuan kreatif, untuk itulah diperlukan metode pembelajaran tematik dengan menggunakan pendekatan lintas disiplin ilmu yang disusun secara berkesinambungan sehingga dapat mengakomodasi kebutuhan siswa. Pembelajaran tematik menekankan partisipasi aktif peserta didik yang sedang mengalami proses pembelajaran berfikir, emosi, dan social. Oleh sebab itu, pembelajaran dengan pendekatan tematik diharapkan muncul saling keterkaitan antar materi yang dipelajari siswa dan dengan pengalaman sehari-hari.

\section{Pembelajaran Bahasa Arab}

Pembelajaran ialah proses interaksi peserta didik dengan pendidik dan sumber belajar pada suatu lingkungan baik lingkungan pendidikan formal maupun nonformal (Balitbang Depdiknas 2002:1). Hal ini menunjukkan bahwa pembelajaran merupakan suatu kegiatan yang dilakukan oleh pendidik dan peserta didik dalam suatu lingkungan belajar tertentu dengan memanfaatkan sumber-sumber belajar yang relevan dan berpedoman pada kurikulum yang berlaku. Pembelajaran harus dirancang direncanakan sedemikian rupa agar peserta didik dapat mencapain tujuan dari pembelajaran tersebut. Maka dapat disimpulkan, pembelajaran merupakan rangkaian proses yang dilakukan oleh guru agar peserta didik belajar dan mencapai tujuan yang telah ditentukan.

Dalam kehidupan manusia bahasa menjadi salah satu kebutuhan dasar dan penting. Bahasa merupakan media penyampai ide, gagasan dan pikiran manusia, baik dalam bentuk ucapan maupun tulisan dengan maksud agar apa yang disampaikan dapat dipahami oleh orang lain. Diantara bahasa-bahasa dunia tersebut bahasa Arab menjadi bahasa tertua dan paling lama digunakan di dunia ini. Sejak al-Qur'an diturunkan dan agama Islam semakin berkembang, penutur bahasa Arab semakin bertambah hingga kini dituturkan oleh lebih dari 200.000 umat manusia. Bahasa ini digunakan secara resmi oleh kurang lebih 20 negara. Alasan lainnya karena bahasa Arab adalah bahasa kitab suci dan tuntunan agama umat Islam sedunia, maka tentu saja ia merupakan bahasa yang paling besar signifikansinya bagi milyaran muslim sedunia, baik yang berkebangsaan Arab maupun bukan Arab (Andriani 2015:39-40). 
Ridho (2018:20) menjelaskan bahwa pembelajaran bahasa Arab sebagai bahasa asing sudah sejak lama dipelajari di Indonesia baik secara formal maupun non formal mulai dari sekolah dasar hingga perguruan tinggi. Hal ini disebabkan karena bahasa Arab berfungsi sangat besar bagi masyarakat Indonesia, yaitu sebagai bahasa keagamaan, kebudayaan, ilmu pengetahuan, juga sebagai bahasa komunikasi dengan bangsa-bangsa Arab. Sampai saat ini, bahasa Arab masih dianggap oleh sebagian besar peserta didik sebagai bahasa yang sulit dipelajari, bahkan dipandang sebagai bidang studi yang tidak disukai. Begitu pula dalam hal pelaksanaan pengajarannya, banyak permasalahan-permasalahan yang dihadapi, mulai dari tingkat dasar hingga tingkat perguruan tinggi.

\section{Pembelajaran Bahasa Arab Berbasis Tematik}

Pendekatan tematik dalam pembelajaran bahasa Arab sering disebut dengan pendekatan interdisipliner. Model pembelajaran tematik pada dasarnya ialah suatu bentuk pembelajaran yang memungkinkan para peserta didik baik secara individual maupun kelompok aktif mencari, menggali, dan menemukan konsep serta prinsipprinsip secara menyeluruh dan dapat dipercaya. Salah satu di antaranya adalah memadukan beberapa Kompetensi Dasar yang harus dikuasai oleh peserta didik. Melalui pembelajaran termatik peserta didik dapat mendapat pengalaman langsung, sehingga mampu menambah kemampuan untuk menerima, menyimpan, dan memproduksi kesan-kesan tentang hal-hal yang dipelajarinya. Dengan demikian, peserta didik selalu terlatih untuk dapat menemukan secara mandiri berbagai konsep yang dipelajari.

Setiyati (2013:72) menyebutkan Pembelajaran tematik lebih menekankan pada keterlibatan siswa dalam proses belajar secara aktif dalam proses pembelajaran, sehingga siswa dapat memperoleh pengalaman langsung dan terlatih untuk dapat menemukan sendiri berbagai pengetahuan yang dipelajarinya. Melalui pengalaman langsung siswa akan memahami konsep -konsep yang mereka pelajari dan menghubungkannya dengan konsep lain yang telah dipahaminya. Pembelajaran tematik memerlukan guru yang kreatif baik dalam menyiapkan kegiatan dan pengalaman belajar bagi anak, juga dalam memilih kompetensi dari berbagai mata pelajaran dan mengaturnya agar pembelajaran menjadi lebih bermakna, menarik menyenangkan dan utuh.

Dalam pendekatan pembelajaran termatik, pembelajaran bahasa Arab disusun dari berbagai macam keterampilan berbahasa, yaitu mendengar (istima), membaca (qiraah),berbicara (kalam) dan menulis (kitabah) dalam satu topik di materi pembelajaran. Pengembangan pembelajaran termatik dalam hal ini, dapat mengambil suatu topik dalam materi pemebelajarannya, kemudian dilengkapi, dibahas, diperluas, dan diperdalam dengan beberapa keterampilan berbahasa. Topik atau tema dapat dikembangkan dari isu, peristiwa, dan permasalahan yang berkembang yang bersifat konstektual.

Dalam penerapan pendekatan pembelajaran tematik kegiatan pembelajaran meliputi tiga kegiatan pokok, yaitu kegiatan pendahuluan, kegiatan inti, dan kegiatan penutup. Kegiatan pendahuluan bertujuan untuk menciptakan suasana awal pembelajaran yang efektif dan efesien yang memungkinkan peserta didik dapat 
mengikuti proses pembelajaran dengan baik. Sebagai contoh ketika memulai pembelajaran, pendidik menyapa peserta didik dengan salam pembuka diimbangi nada semangat dan gembira (salam sebagai karakter religius), mengecek kehadiran para siswa dan menanyakan ketidak hadiran peserta didik apabila ada yang tidak hadir (penanaman karakter jujur). Dalam metode pendekatan pembelajaran tematik tujuan kegiatan pendahuluan adalah memantapkan pemahaman peserta didik terhadap konsepkonsep yang telah dikuasai yang berkaitan dengan materi pelajaran baru yang akan dipelajari oleh peserta didik. Dalam kegiatan ini pendidik harus berusaha mengupayakan agar peserta didik yang belum paham suatu konsep dapat memahami konsep tersebut, sedangkan peserta didik yang mengalami kesalahan konsep, kesalahan tersebut dapat dihilangkan (Umam 2018:128).

Pendekatan tematik dalam pembelajaran memiliki beberapa landasan, yaitu:

1. Landasan filosofis dalam pembelajaran tematik sangat dipengaruhi oleh tiga aliran filsafat yaitu: (1) progresivisme, (2) konstruktivisme, dan (3) humanisme. Aliran progresivisme memandang bahwa proses pembelajaran perlu terfokus pada pembentukan kreatifitas, pemberian sejumlah kegiatan, suasana yang alamiah (natural), dan memperhatikan pengalaman siswa. Aliran konstruktivisme melihat pengalaman langsung siswa (direct experiences) sebagai kunci dalam pembelajaran. Sedangkan aliran humanisme melihat siswa dari segi keunikan/kekhasannya, potensinya, dan motivasi yang dimilikinya.

2. Landasan psikologis dalam pembelajaran tematik terutama berkaitan dengan psikologi perkembangan peserta didik dan psikologi belajar. Psikologi perkembangan diperlukan terutama dalam menentukan isi/materi pembelajaran tematik yang diberikan kepada siswa agar tingkat keluasan dan kedalamannya sesuai dengan tahap perkembangan peserta didik.

3. Landasan hukum dalam pembelajaran tematik berkaitan dengan berbagai kebijakan atau peraturan yang mendukung pelaksanaan pembelajaran tematik di sekolah dasar. Landasan hukum tersebut adalah UU No. 23 Tahun 2002 tentang Perlindungan Anak yang menyatakan bahwa setiap anak berhak memperoleh pendidikan dan pengajaran dalam rangka pengembangan pribadinya dan tingkat kecerdasannya sesuai dengan minat dan bakatnya (Depdiknas 2006:3)

Pembelajaran berbasis pendekatan tematik mempunyai karakteristik sebagai berikut:

1. Pembelajaran berpusat pada peserta didik. Hal ini dikarenakan pembelajaran bahasa Arab dengan pendekatan tematik merupakan suatu pendekatan pembelajaran yang memberikan kebebasan pada peserta didik, baik secara individu maupun kelompok. Peserta didik diharapkan mampu aktif mencari dan menggali konsep serta prinsip-prinsip dari suatu pengetahuan yang harus dikusainya.

2. Pendekatan tematik memberi pengalaman langsung kepada peserta didik. Pembelajaran bahasa Arab dengan pendekatan tematik mengaitkan antar konsep dan prinsip yang pelajari dari beberapa 
keterampilan dalam bahasa Arab.

3. Penyatuan keterampilan bahasa dalam satu materi. Sehingga memungkinkan peserta didik untuk memahami materi pembelajaran dari segala sisi yang utuh, tanpa adanya pemisahan keterampilan bahasa Arab yang harus dikusai.

4. Menyajikan konsep dari berbagai keterampilan bahasa dalam suatu pembelajaran sehingga bermakna.

5. Hasil pembelajaran dapat berkembang sesuia dengan minat dan kebutuhan

6. Pembelajaran bahasa Arab dapat berlangsung fleksibel dan lebih efesien.

Pembelajaran bahasa Arab dengan pendekatan tematik memiliki sejumlah manfaat, yaitu:

1. Pembelajaran mampu meningkatkan pemahaman konseptual peserta didik terhadap realitas sesuai dengan tingkat perkembangan intelektualitasnya

2. Peserta didik mudah memusatkan perhatian karena beberapa keterampilan berbahasa dikaitkan dalam satu tema yang sama.

3. Peserta didik dapat mempelajari pengetahuan dan mengembangkan berbagai keterampilan bahasa Arab dalam tema yang sama.

4. Pendekatan tematik melatih peserta didik untuk banyak membuat hubungan beberapa keterampilan bahasa, sehingga mampu memproses informasi dengan cara yang sesuai daya pikir dan memungkinkan berkembang jaringan konsep.

5. Menghemat waktu karena beberapa keterampilan dikemas dalam tema dan disajikan terpadu dalam alokasi yang telah direncanakan (Wulandari, 2009:15)

\section{Kesimpulan}

Pendekatan tematik dalam pembelajaran bahasa Arab merupakan model yang akan menciptakan sebuah pembelajaran yang terpadu, mendorong keterlibatan siswa dalam belajar, membuat siswa aktif terlibat dalam proses pembelajaran dan menciptakan situasi pemecahan masalah sesuai dengan kebutuhan siswa. Melalui pembelajaran secara tematik peserta didik akan mampu belajar dengan kreativitas yang tinggi. Pendekatan tematik juga dapat diartikan sebagai suatu pola pembelajaran yang mengintegrasikan pengetahuan, keterampilan, kemahiran, nilai dan sikap pembelajaran dengan menggunakan tema.

Pendekatan tematik dalam pembelajaran bahasa Arab dikembangkan selain untuk mencapai tujuan pembelajaran yang telah ditetapkan, diharapkan siswa juga dapat meningkatkan pemahaman konsep yang dipelajarinya secara lebih bermakna, mengembangkan keterampilan menemukan, mengolah, dan memanfaatkan informasi, menumbuh kembangkan sikap positif, kebiasaan baik, dan nilai- nilai luhur yang diperlukan dalam kehidupan, menumbuh kembangkan keterampilan sosial seperti kerja sama, toleransi, komunikasi, serta menghargai pendapat orang lain, meningkatlkan gairah dalam belajar dan memilih kegiatan yang sesuai dengan minat dan 
kebutuhannya.

\section{Daftar Pustaka}

Anwar Novianto, A. M. (2015). Analisis Buku Teks Muatan Tematik Integratif, Scientific Approach, Dan Authentic Assessment Sekolah Dasar. Jurnal Kependidikan: Penelitian Inovasi Pembelajaran, 45(1), 109685. https://doi.org/10.21831/jk.v45i1.7181

Darwis Sasmedi, dkk. (2008). Implementasi Pembelajaran Tematik Pada kelas Awal Sekolah Dasar di Provinsi Sulawesi Selatan. JURNAL ILMU KEPENDIDIKAN, 5(1), 78-96.

Ariyanti, P. (2017). Manajemen Pembelajaran Dengan Menggunakan Pendekatan Tematik Integratif Di Sd Negeri Tugu Kecamatan Purwoasri Kediri. Jurnal Manajemen Pendidikan, 1, 0-9.

Kartini, T. (2012). Pendekatan Tematik Dalam Pembelajaran IPS. EduHumaniora| Jurnal Pendidikan Dasar Kampus Cibiru, 2(2).

Nahak, K. E. N., Degeng, I. N. S., \& Widiati, U. (2019). Pembelajaran Tematik di Sekolah Dasar. Jurnal Pendidikan:Teori, Penelitian, Dan Pengembangan, 4(6), 785-794.

Mohamad Muklis. (2012). PEMBELAJARAN TEMATIK. Fenomena, IV(20), 63-76.

Andriani, A. (2015). Urgensi Pembelajaran Bahasa Arab dalam Pendidikan Islam. Ta'allum: Jurnal Pendidikan Islam, 3(1), 39-56.

Pusat Kurikulum, Balitbang Depdiknas. Pelaksanaan Kurikulum Berbasis Kompetensi ( Jakarta: Balitbang Depdiknas. 2002), Hal 1.

Ridho, U. (2018). Evaluasi Dalam Pembelajaran Bahasa Arab. An Nabighoh: Jurnal Pendidikan Dan Pembelajaran Bahasa Arab, 20(01), 19-26.

Setiyati, E. (2013). Peningkatan Kemampuan Membuat RPP dan Menerapkan Pembelajaran dengan Pendekatan Tematik Melalui Pembinaan Akademik Lewat Pemberdayaan KKG bagi Guru SD.

Umam, M. K. (2018, February). Paradigma Pendidikan Profetik dalam Pendekatan Pembelajaran Tematik di Madrasah Ibtida'iyah. In PROCEEDING: The Annual International Conference on Islamic Education (Vol. 3, No. 1, pp. 120-132).

Depdiknas, Model Pembelajaran Tematik Kelas Awal Sekolah dasar, Jakarta; Depdiknas, 2006

Sukayati, Sukayati and Sri, Wulandari (2009) Pembelajaran tematik di SD. PPPPTK Matematika, Yogyakarta. 